\title{
A METABOLIC STUDY OF A DIABETIC PATIENT: THE EFFECT OF VARIATIONS IN THE DOSAGE OF INSULIN UPON ADRENAL CORTICAL ACTIVITY AND UPON WATER, ELECTROLYTE AND NITROGEN EXCRETION ${ }^{1}$
}

\author{
By J. W. McARTHUR, D. H. C. CHAO, E. A. MAcLACHLAN, M. F. MORRILL, A. M. \\ CAMPBELL, M. D. WOOD, A. ZYGMUNTOWICZ, F. C. GOETZ, AND \\ S. L. SVEINSSON \\ (From the Burnham Memorial Hospital for Children at the Massachusetts General Hospital, \\ and the Department of Pediatrics, Harvard Medical School, Boston, Mass.)
}

(Submitted for publication December 14, 1951 ; accepted April 14, 1952)

That alterations in adrenal cortical structure and function may accompany diabetes mellitus is indicated by a number of observations. Untreated alloxan-diabetic rats, for example, exhibit both gross (1) and microscopic (2) evidence of adrenal cortical hypertrophy, suggesting that adrenal cortical hyperfunction may accompany diabetes, at least in the absence of insulin therapy. Diabetic patients, on the other hand, tend to excrete 17-ketosteroids (3) and perhaps corticosteroids (4) at a lowered rate, and to react to surgical trauma with abnormally transient eosinopenia (5), suggesting that under certain circumstances there may be hypofunction, and possibly partial exhaustion, of the adrenal cortex.

Of the various metabolic abnormalities which might produce hyperfunction and ultimate attrition of the adrenal cortex in diabetic patients, instability in the control of the blood sugar level appeared to us to merit primary consideration inasmuch as hypoglycemia and hyperglycemia, states between which the diabetic patient oscillates continuously, are both capable of stimulating the adrenal cortex $(6-16)$. The present study was designed to determine whether there was any relation between the degree of control of blood sugar and the level of adrenal cortical activity. Serial measurements of the level of the blood sugar, the eosinophil count, the rate of urinary excretion of corticosteroids, and of certain other variables, have been made on a diabetic patient over 15-day periods during which crystalline insulin in dosage levels

1 This work was supported by grants from the National Institutes of Health, Public Health Service; the Committee on Research in Endocrinology, National Research Council; the Commonwealth Fund of New York and the American Cancer Society. ranging from 25 to 80 units per day was administered.

\section{EXPERIMENTAL PROCEDURE}

The subject of these studies was a physically vigorous 19-year-old male in whom mongolism had been recognized for 18 years and diabetes mellitus for 12 years. For at least three years prior to these studies asymptomatic pyelonephritis had been present. White cells were continuously present in the urine, from which $B$. pyocyaneus could be cultured, despite repeated courses of sulfadiazine, streptomycin and aureomycin. However, no obstruction could be demonstrated in the urinary tract and the urea clearance test was normal. The renal threshold for glucose was elevated. Adrenal responsiveness was normal, as judged by the ACTH-eosinophil test.

At the time that these observations were made, the patient was 57.75 inches $(144.4 \mathrm{~cm}$.) tall and weighed 110 pounds $(50 \mathrm{Kg}$.). Except for the short stature and mental retardation, positive physical findings consisted only of mongoloid features and hypertrophied tonsils. While he was at home, the patient's diabetes was reasonably well controlled on a 2,000 calorie diet by the administration of 40 units of protamine zinc insulin and 16 units of regular insulin in separate sites before breakfast. Insulin reactions had been rare and although he had become mildly acidotic on a few occasions, he had never been in diabetic coma.

These studies were conducted on a metabolic ward at intervals over a period of 12 months. The diet, which was maintained constant throughout, consisted of carbohydrate 193, protein 106, and fat 95 grams and provided 2,056 calories. Five grams of sodium chloride were added to the diet, making the total intake of sodium 126.1 mEq. per day, chloride $129.1 \mathrm{mEq}$., potassium $118.5 \mathrm{mEq}$., and nitrogen 16.9 grams per day. Four isocaloric feedings, together with an injection of crystalline insulin, were given at six-hour intervals. No limitation was placed upon the fluid intake. During periods when attempts were made to maintain the blood sugar within normal limits and insulin reactions occurred, $10 \mathrm{gram}$ packets of glucose were provided for administration at the first indication of hypoglycemia. It was possible to 
maintain the patient's physical activity relatively constant except during the spring season, when he frequently escaped observation and exercised vigorously out of doors. He was found several times in a semi-conscious state and on one occasion the use of intravenous glucose was required to terminate clonic convulsions. On this account the period of normoglycemia attempted during the spring was repeated during the winter when the amount of exercise taken could be more easily controlled. During the winter period constant surveillance of the patient was maintained by an attendant employed solely for this purpose, and light exercise only was permitted. Hypoglycemic reactions, which were few in number, were arrested promptly at their inception.

To facilitate insulin regulation the urine was collected in six-hour pools and a rapid quantitative estimation of the glucose content was made by the Somogyi (17) method. The dosage of crystalline insulin was so adjusted as to achieve as stable a degree of glycosuria (or, during aglycosuric periods, as stable a level of blood sugar) as possible during the selected regime of control. Five insulin dosage levels ranging from 25 to 80 units were employed over periods of 15 days each. Dosage levels were selected which would permit (a) maximal glycosuria without ketonuria, (b) moderate glycosuria, (c) aglycosuria with hyperglycemia, and (d) normoglycemia. (The normoglycemic regime was undertaken on two separate occasions for reasons previously explained.) Intervals of at least three weeks were permitted to elapse between the 15-day metabolic periods.

Quantitative analyses of the 24-hour urine specimens were made for creatinine and sugar. Specimens whose creatinine content indicated them to be complete ${ }^{2}$ were either analyzed individually or, during certain periods, were combined into three-day pools for determination of

2 While difficulty in securing complete collections was anticipated due to the patient's mental impairment, few specimens had, in fact, to be discarded. the rate of excretion of sodium, chloride, potassium, nitrogen and corticosteroids. The blood sugar having been found to be minimal one hour before and maximal one hour after meals, the range of blood sugar during a given regime was established by frequent measurements taken at these times. An eosinophil count was made from venous blood drawn at 3 p.m. daily.

\section{METHODS}

Sodium was determined by the method of Butler and Tuthill (18), chloride by a modification of the method of Wilson and Ball (19), potassium by the method of Fiske and Litarczek (20), nitrogen by the macro-Kjeldahl method of Peters and Van Slyke (21), and creatinine by a modification of the method of Bonsnes and Taussky (22). Blood and urinary glucose were estimated by the methods of Folin $(23,24)$. The urinary corticosteroids were measured by the method of Talbot, Saltzman, Wixon, and Wolfe (25).

Circulating blood eosinophils were counted in the doublecelled Fuchs-Rosenthal chamber by a modification of the method of Randolph (26). Two U. S. Bureau of Standards certified pipettes were employed, and all of the eosinophils in both cells of four chambers counted.

\section{RESULTS}

The effect which the different dosage levels of insulin exerted upon the blood glucose, urinary glucose excretion, urine volume, eosinophil count and urinary corticosteroid excretion is summarized in Table I; the effect upon the body weight and the urinary excretion of nitrogen and electrolytes is summarized in Table II.

During the period of maximal glycosuria the urine volume increased over that observed during

TABLE I

The effect of various degrees of control upon the blood and urine glucose, the urine volume, the eosinophil count and the corticosteroid excretion rate of a diabetic patient

\begin{tabular}{|c|c|c|c|c|c|c|c|}
\hline \multirow{2}{*}{ Regime } & \multirow{2}{*}{$\begin{array}{c}\text { Mean dosage } \\
\text { of crystalline } \\
\text { insulin } \\
(U / 24 \text { hrs. })\end{array}$} & \multirow{2}{*}{$\begin{array}{c}\text { Range of } \\
\text { blood glucose } \\
\text { (mgm. \%) }\end{array}$} & \multirow{2}{*}{$\left|\begin{array}{c}\text { Mean urinary } \\
\text { glucose } \\
\text { excretion } \\
\text { (gm./24 hrs. })\end{array}\right|$} & \multirow{2}{*}{$\begin{array}{l}\text { Mean urine } \\
\text { volume } \\
\text { (cc./24 hrs.) }\end{array}$} & \multicolumn{2}{|c|}{$\begin{array}{l}\text { Eosinophil count at } \\
3 \mathrm{p.m} \\
\left.\text { (cells } / \mathrm{mm}^{\prime} .\right)\end{array}$} & \multirow{2}{*}{$\begin{array}{l}\text { Mean corti- } \\
\text { costeroid } \\
\text { excretion } \\
\text { rate } \\
\text { (mgm./24hrs.) }\end{array}$} \\
\hline & & & & & Mean & S.D. & \\
\hline $\begin{array}{l}\text { Maximal glycosuria without ketonuria } \\
\text { Moderate glycosuria } \\
\text { Aglycosuria with hyperglycemia } \\
\text { Normoglycemia (spring) } \\
\text { (a) Days 1-5 } \\
\text { (b) Days 6-10 } \\
\text { (c) Days 11-15 } \\
\text { Normoglycemia (winter) } \\
\text { (a) Days 1-5 } \\
\text { (b) Days 6-10 } \\
\text { (c) Days 11-15 }\end{array}$ & $\begin{array}{l}25 \\
39 \\
55 \\
70 \\
79 \\
77\end{array}$ & $\begin{array}{l}328-461^{*} \\
270-445 \dagger \\
244-407 \dagger\end{array}$ & $\begin{array}{c}124.3 \\
58.2 \\
0 \\
0 \\
0 \\
0\end{array}$ & $\begin{array}{l}3,212 \\
2,721 \\
2,780 \\
\\
3,230 \\
3,786 \\
4,528\end{array}$ & $\begin{array}{l}190 \\
182 \\
197 \\
- \\
-\end{array}$ & $\begin{array}{l}25.5 \\
18.8 \\
17.5 \\
- \\
-\end{array}$ & $\begin{array}{l}0.20 \\
0.26 \\
0.25 \\
\\
2.81 \\
4.07 \\
5.64\end{array}$ \\
\hline
\end{tabular}

*Venous.

† Capillary. 
TABLE II

The effect of various degrees of control upon the urinary excretion of electrolytes and nitrogen by a diabetic patient

\begin{tabular}{|c|c|c|c|c|c|c|c|c|c|c|}
\hline \multirow{2}{*}{ Regime } & \multirow{2}{*}{$\begin{array}{c}\text { Mean } \\
\text { dosage of } \\
\text { crystalline } \\
\text { insulin } \\
(U / 24 \text { hrs. })\end{array}$} & \multicolumn{2}{|c|}{$\underset{(m E q . / 24 \text { hrs. })}{\text { Sodium }_{(m}}$} & \multicolumn{2}{|c|}{$\begin{array}{c}\text { Chloride } \\
(m E q . / 24 \text { hrs. })\end{array}$} & \multicolumn{2}{|c|}{$\underset{(m E q . / 24 \text { hrs. })}{\text { Potassium }}$} & \multicolumn{2}{|c|}{$\underset{(\mathrm{gm} . / 24 \mathrm{hrs.})}{\text { Nitrogen }}$} & \multirow{2}{*}{$\begin{array}{c}\text { Change } \\
\text { in Body } \\
\text { weight } \\
\left(K_{g} .\right)\end{array}$} \\
\hline & & Mean & S. D. & Mean & S. D. & Mean & S. D. & Mean & S. D. & \\
\hline $\begin{array}{l}\text { Maximal glycosuria without ketonuria } \\
\text { (a) Days 1-5 } \\
\text { (b) Days 6-10 } \\
\text { (c) Days 11-15 } \\
\text { Moderate glycosuria } \\
\text { Aglycosuria with hyperglycemia } \\
\text { Normoglycemia (spring) } \\
\text { Normoglycemia (winter) }\end{array}$ & $\begin{array}{l}25 \\
25 \\
25 \\
39 \\
55 \\
75 \\
80\end{array}$ & $\begin{array}{r}135.0 \\
116.8 \\
107.8 \\
114.1 \\
104.7 \\
99.5 \\
104.5\end{array}$ & $\begin{array}{r}36.7 \\
12.0 \\
7.2 \\
6.9 \\
11.2 \\
4.5 \\
7.0\end{array}$ & $\begin{array}{l}131.5 \\
122.6 \\
113.5 \\
116.4 \\
117.2 \\
110.3 \\
109.0\end{array}$ & $\begin{array}{r}29.3 \\
17.1 \\
3.0 \\
5.6 \\
11.0 \\
7.9 \\
5.3\end{array}$ & $\begin{array}{l}91.3 \\
89.7 \\
88.7 \\
86.0 \\
86.3 \\
75.8 \\
75.8\end{array}$ & $\begin{array}{r}13.5 \\
3.9 \\
6.6 \\
2.9 \\
6.9 \\
2.4 \\
7.4\end{array}$ & $\begin{array}{l}17.1 \\
16.8 \\
17.2 \\
15.1 \\
14.4 \\
13.5 \\
13.0\end{array}$ & $\begin{array}{l}1.6 \\
0.6 \\
1.3 \\
0.3 \\
0.7 \\
0.8 \\
1.2\end{array}$ & $\begin{array}{r}-1.20 \\
-0.32 \\
-0.30 \\
+0.22 \\
+0.67 \\
+0.32 \\
+0.78\end{array}$ \\
\hline
\end{tabular}

periods of moderate glycosuria and aglycosuria with hyperglycemia. Wide fluctuations in daily glucose excretion occurred despite the precautions taken to achieve stability. In Table II, the data for the period of maximal glycosuria have been broken down into three five-day subdivisions in order that the progressive changes which took place in the rate of excretion of sodium and chloride may be apparent. The sudden initiation of glycosuria by a reduction in insulin dosage from 42 to 29 units on the day before the period began was accompanied by an appreciable loss of urinary sodium and chloride. The rate of salt excretion declined during the middle third, and became normal during the final third of the period. The serum sodium and chloride, which remained essentially stationary during all other regimes, fell during the regime of maximal glycosuria. Over the 15 days, the serum sodium declined from 141.6 to 135.5 and the chloride from 100.7 to 97.0 $\mathrm{mEq}$. per liter. Excretion rates for potassium and nitrogen rose to the highest levels observed during the study and remained relatively constant throughout the three subdivisions of the period. The nitrogen balance was consistently negative, whether fecal nitrogen loss was estimated at $10 \%$ of the nitrogen intake or at 1.283 grams per 24 hours, as suggested by Reifenstein, Albright, and Wells (27). Body weight declined rapidly during the first third of the period and more slowly during the remainder. Since no significant changes in the rate of nitrogen excretion occurred, the precipitous early fall in body weight was presumably associated with a loss of extracellular fluid. Despite the loss of salt and nitrogen and the polyuria, the eosinophil count and urinary corticosteroid excretion rate remained within normal limits.

The period of moderate glycosuria was associated with a reduction in the urine volume to the rather large value which was usual for the patient. The rate of sodium and chloride excretion did not differ appreciably from that observed during the final third of the period of maximal glycosuria or during subsequent periods of more rigorous control. The rate of nitrogen and potassium excretion decreased, the nitrogen balance became positive, and a small gain in weight occurred. No significant alteration was observed in the eosinophil count or urinary corticosteroid excretion rate.

During the period of aglycosuria with hyperglycemia, the blood sugar occasionally rose to moderately high levels without a loss of sugar in the urine. The rate of nitrogen excretion decreased still further and weight was gained more rapidly. The eosinophil count and corticosteroid excretion rate remained essentially unchanged.

The two periods of attempted normoglycemia were accompanied by the excretion of large volumes of urine, in amounts which exceeded even those observed during the period of maximal glycosuria. The rate of excretion of nitrogen and potassium declined to the lowest levels observed during these studies. Despite frequent estimations of the level of blood sugar and adjustments of insulin dosage, hypoglycemic reactions often occurred, particularly during the spring when the patient escaped observation. Eosinophil counts became so erratic that representative values could no longer be obtained serially, the eosinophils falling after insulin reactions and subsequently rebounding to high levels. The rate of cortico- 
steroid excretion increased progressively during the normoglycemic regimes, attaining values of $5.64 \mathrm{mgm}$. and $0.54 \mathrm{mgm}$. per 24 hours at the conclusion of the spring and winter regimes, respectively.

\section{DISCUSSION}

(a) Measurements of adrenal cortical activity. The observation that adrenal cortical activity, as judged by the eosinophil count and the rate of corticosteroid excretion, ${ }^{3}$ did not vary in the three regimes characterized by consistent hyperglycemia is in accord with previous studies. Thus, when the present patient was subjected to total insulin deprivation, no indication of adrenal hyperactivity could be demonstrated until mild ketosis and acidosis became manifest (28). Similar findings have been obtained after the withdrawal of insulin from depancreatized dogs (29). Although the administration of glucose has occasioned eosinopenia in acute experiments (16), the induction of a more gradual rise in the blood sugar apparently need not lead to an increase in the rate of corticosteroid excretion. The only finding which suggests the occurrence of adrenal hyperactivity during the hyperglycemic regimes is the striking conservation of urinary sodium and chloride which was gradually effected during the period of maximal glycosuria. ${ }^{4}$ While this economy may have been achieved through the activation of an idiorenal mechanism, it is possible that increased secretion of an adrenocortical "salt" hormone was responsible.

The finding that adrenal hyperactivity accompanied the normoglycemic regimes, with their recurring insulin reactions, agrees with many previous observations concerning the physiological effects of hypoglycemia. However, the magnitude of the rise in corticosteroid excretion which oc-

\footnotetext{
8 Until the intermediary metabolism of steroids has been more completely clarified, the possibility that corticosteroid excretion may be low despite high secretion because of rapid tissue utilization must, of course, be conceded.

4 Had ketonuria been permitted progressive base conservation could not, in all probability, have been demonstrated (note the continuous loss of base by Atchley's and associates' [30] patient W. O'C. during 11 days' total insulin deprivation).
}

curred during the spring regime occasioned some surprise.

The moderate increase in the amount of physical activity taken by the patient during the spring regime undoubtedly influenced adrenal secretory activity somewhat. However, it seems unlikely that this factor alone could account for the heightened rate of corticosteroid excretion during the spring, as compared with the winter, regime. The amount of exercise taken was far less than that habitually enjoyed by mentally normal boys of the same age. The fact that no increase in insulin dosage was required to preserve approximate normoglycemia was unanticipated; it had been expected that adrenal hyperactivity of the degree observed would lead to insulin resistance.

(b) General metabolic observations. The loss of sodium and chloride which occurred during the early phases of the period of heavy glycosuria was anticipated from the results of previous acute experiments (31-33). The conservation of salt which was gradually effected despite continuing glycosuria was, however, unexpected. The mechanism by which such conservation is accomplished merits investigation.

The large urine volume observed during the periods of attempted normoglycemia was conceivably a manifestation of "stress." Both Lloyd (34) and Corcoran, Dustan, and Page (35) have noted the existence of a positive coefficient of correlation between urine volume and corticosteroid excretion rate.

The inverse relationship found to exist between the rate of urinary nitrogen and potassium excretion and the dose of insulin administered presumably reflects the capacity of insulin to accelerate the rate of protein synthesis $(36-42)$.

In so far as it is permissible to generalize from studies on a single patient, these short-term descriptive experiments suggest that the rigor of the therapeutic regimen may exert a significant effect upon adrenal cortical activity in the diabetic patient. Strict regimes of control, with their tendency to recurrent insulin reactions, appear to be accompanied by an accelerated rate of release of corticosteroids. Lenient regimes appear to be associated with increased corticosteroid secretion only when prolonged hyperglycemia has led secondarily to ketoacidosis. That regimes permitting 
heavy glycosuria may be accompanied by an accelerated rate of release of mineralocorticoids is suggested, although not proved, by the data presented.

The long-term effects of therapeutic regimes of different severity can only be surmised. It is conceivable that maintenance of a high level of adrenal cortical function reduces the quantum of "adaptation energy" (43) available to meet extraneous stresses and predisposes ultimately to adrenal exhaustion. In this connection, the observation of Field and Marble (5) that there is an inverse correlation between the duration of diabetes and the degree of adrenal cortical responsiveness to surgical trauma may be pertinent.

The maintenance of a high concentration of adrenal cortical hormones in the circulation of a diabetic patient almost certainly exerts widespread biologic effects; whether the over-all consequences of these effects are beneficial or harmful to the diabetic organism remains to be determined by painstaking investigation.

\section{SUMMARY}

Crystalline insulin in dosage levels ranging from 25 to 80 units was administered for periods of 15 days to a patient with mongolism and diabetes mellitus while he was maintained on a constant diet and unlimited fluids. Dosage levels were selected which would permit, (a) maximal glycosuria without ketonuria, (b) moderate glycosuria, (c) aglycosuria with hyperglycemia, and (d) normoglycemia. The level of adrenal cortical function was estimated by means of serial eosinophil counts and urinary corticosteroid determinations, and the rates of urinary excretion of nitrogen, sodium, chloride, and potassium were also measured.

The dosage of insulin was found to exert a significant influence upon the rate of corticosteroid excretion and the eosinophil count, as well as upon the rates of excretion of water, electrolytes, and nitrogen. The administration of large doses of insulin in attempts to insure continuous normoglycemia resulted in the occurrence of frequent insulin reactions and in measurable increases in the rate of corticosteroid excretion. The administration of small doses which just prevented ketonuria exerted no detectable effect upon the rate of corticosteroid excretion or the eosinophil count although a heavy glycosuria ensued. That an adrenocortical "salt" hormone was perhaps secreted during this regime is suggested by the fact that conservation of sodium and chloride was gradually effected despite continuing glycosuria.

Urine volumes were greatest during the periods of attempted normoglycemia when they exceeded even those observed during the period of maximal glycosuria. There were no significant alterations in sodium and chloride excretion rates except during the initial period of maximal glycosuria. During the early phases of this period a loss of salt accompanied that of glucose. The rate of excretion of potassium and nitrogen varied inversely with the dose of insulin administered.

\section{ACKNOWLEDGMENT}

The authors wish to express their appreciation to the Misses Marion MacAulay, Nancy Di Mattia, Marilyn Poulter, and Ruth Ball, nurses on the metabolic ward, for invaluable assistance in conducting this study.

\section{REFERENCES}

1. Bennett, L. L., and Koneff, A. A., Atrophy of the thyroid and hypertrophy of the adrenal in rats with alloxan diabetes. Anat. Rec., 1946, 96, 1.

2. Applegarth, A., Histochemical changes in the adrenal cortex of the rat in alloxan diabetes. Endocrinology, 1949, 44, 197.

3. Miller, S., and Mason, H. L., The excretion of $17-$ ketosteroids by diabetics. J. Clin. Endocrinol., 1945, $5,220$.

4. Talbot, N. B., Wood, M. S., Worcester, J., Christo, E., Campbell, A. M., and Zygmuntowicz, A. S., Further observations on the urinary excretion of water-soluble corticosteroids by normal and abnormal subjects. J. Clin. Endocrinol., 1951, 11, 1224.

5. Field, J. B., and Marble, A., Diminished adrenal cortical function in diabetes as shown in eosinophil response to stress of surgery. Proc. Soc. Exper. Biol. \& Med., 1951, 77, 195.

6. Baird, E. E., and Dixon, K. P., The effect of insulin on the blood picture. Am. J. Clin. Path., 1948, 18, 470.

7. Gershberg, H., and Long, C. N. H., The activation of the adrenal cortex by insulin hypoglycemia. J. Clin. Endocrinol., 1948, 8, 587.

8. Godlowski, Z. Z., Eosinopenia caused by adrenaline infusion and by insulin hypoglycemia. Brit. M. J., 1948, 1, 46.

9. Langecker, H., Der Einfluss chronischer Insulinzu- 
fuhr auf die Nebennieren beim Kaninchen. Arch. f. exper. Path. u. Pharmakol., 1928, 134, 155.

10. Laragh, J. H., and Almy, T. P., Changes in circulating eosinophils in man following epinephrine, insulin and surgical operations. Proc. Soc. Exper. Biol. \& Med., 1948, 69, 499.

11. Miller, R. A., and Riddle, O., Cellular response to insulin in suprarenals of pigeons. Proc. Soc. Exper. Biol. \& Med., 1941, 47, 449.

12. Paschkis, K. E., Cantarow, A., and Boyle, D., Adrenal cortical hormone levels in blood following "alarming stimuli." Federation Proc., 1949, 8, 123.

13. Randall, L. O., Effect of repeated insulin hypoglycemia on the lipid composition of rabbit tissues. J. Biol. Chem., 1940, 133, 129.

14. Riddle, O., Honeywell, H. E., and Fisher, W. S., Suprarenal enlargement under heavy dosage with insulin. Am. J. Physiol., 1924, 68, 461.

15. Tsai, S. Y., Bennett, A., May, L. G., and Gregory, R. L., Effect of insulin hypoglycemia on eosinophils and lymphocytes of psychotics. Proc. Soc. Exper. Biol. \& Med., 1950, 74, 782.

16. Jordan, P. H., Last, J. H., Pitesky, I., and Bond, E., Eosinopenia due to glucose administration. Proc. Soc. Exper. Biol. \& Med., 1950, 73, 243.

17. Somogyi, M., A rapid method for the estimation of urine sugar. J. Lab. \& Clin. Med., 1941, 26, 1220.

18. Butler, A. M., and Tuthill, E., An application of the uranyl zinc acetate method for determination of sodium in biological material. J. Biol. Chem., 1931, 93, 171.

19. Wilson, D. W., and Ball, E. G., A study of the estimation of chloride in blood and serum. J. Biol. Chem., 1928, 79, 221.

20. Fiske, C. H., and Litarczek, G., Unpublished method cited by Folin, O., in Laboratory Manual of Biological Chemistry. D. Appleton-Century Co., New York and London, 1934, 5th edition, pp. 239, 353.

21. Peters, J. P., and Van Slyke, D. D., Quantitative Clinical Chemistry. Vol. II, Methods. Williams \& Wilkins. Baltimore, 1932, pp. 516-538.

22. Bonsnes, R. W., and Taussky, H. H., On the colorimetric determination of creatinine by the Jaffe reaction. J. Biol. Chem., 1945, 158, 581.

23. Folin, O., The micro method for the determination of blood sugar. New England J. Med., 1932, 206, 727.

24. Folin, O., and Berglund, H., A colorimetric method for the determination of sugars in normal human urine. J. Biol. Chem., 1922, 51, 209.

25. Talbot, N. B., Saltzman, A. H., Wixon, R. L., and Wolfe, J. K., A colorimetric assay of urinary corticosteroid-like substances. J. Biol. Chem., 1945, 160, 535.

26. Randolph, T. G., Blood studies in allergy. I. The direct counting chamber determination of eosinophils by propylene glycol aqueous stains. J. Allergy, 1944, 15, 89.
27. Reifenstein, E. C., Albright, F., and Wells, S. L., The accumulation, interpretation and presentation of data pertaining to metabolic balances, notably those of calcium, phosphorus and nitrogen. J. Clin. Endocrinol., 1945, 5, 367.

28. McArthur, J. W., Sprague, R. G., and Mason, H. L., The urinary excretion of corticosteroids in diabetic acidosis. J. Clin. Endocrinol., 1950, 10, 307.

29. McArthur, J. W., Harting, D., Smart, G. A., and Talbot, N. B., Time relations between the metabolic changes of experimental diabetic acidosis and adrenal cortical hyperfunction. J. Clin. Invest., 1950, 29, 832.

30. Atchley, D. W., Loeb, R. F., Richards, D. W., Jr., Benedict, E. M., and Driscoll, M. E., On diabetic acidosis. A detailed study of electrolyte balances following the withdrawal and reestablishment of insulin therapy. J. Clin. Invest., 1933, 12, 297.

31. Hendrix, B. M., Fay, M., Calvin, D. B., and Bodansky, M., The effect of excretion of acids and bases upon the development of acidosis in experimental diabetes. J. Biol. Chem., 1926, 69, 449.

32. Kerpel-Fronius, రั., Zur Frage des diabetischen Salzmangelzustandes. Klin. Wchnschr., 1937, 16, 1466.

33. Brodsky, W. A., Rapoport, S., and West, C. D., The mechanism of glycosuric diuresis in diabetic man. J. Clin. Invest., 1950, 29, 1021.

34. Lloyd, C. W., Personal communication quoted by Gaunt, R., Birnie; J. H., and Eversole, W. J., Adrenal cortex and water metabolism. Physiol. Rev., 1949, 29, 281.

35. Corcoran, A. C., Dustan, H. P., and Page, I. H., Enzymatically hydrolyzable formaldehydogenic corticoids : normal values and observations on disease states. J. Clin. Invest., 1951, 30, 633.

36. Mirsky, I. A., The influence of insulin on the protein metabolism of nephrectomized dogs. Am. J. Physiol., 1938, 124, 569.

37. Mirsky, I. A., The influence of the anterior pituitary gland on protein metabolism. Endocrinology, 1939, 25, 52.

38. Luetscher, J. A., Jr., The metabolism of amino acids in diabetes mellitus. J. Clin. Invest., 1942, 21, 275.

39. Frame, E. G., and Russell, J. A., The effects of insulin and anterior pituitary extract on the blood amino nitrogen in eviscerated rats. Endocrinology, 1946, 39, 420.

40. Lotspeich, W. D., The role of insulin in the metabolism of amino acids. J. Biol. Chem., 1949, 179, 175.

41. Lotspeich, W. D., Relations between insulin and pituitary hormones in amino acid metabolism. J. Biol. Chem., 1950, 185, 221.

42. Chaikoff, I. L., and Forker, L. L., The antidiabetic action of insulin on nitrogen metabolism. Endocrinology, 1950, 46, 319.

43. Selye, $H$., The general adaptation syndrome and the diseases of adaptation. J. Clin. Endocrinol., 1946, $6,117$. 